\title{
TEMPORAL VENTURES ROBBED ME
}

\author{
Wish you were here?
}

\section{BY SCOTT C. MIKULA}

Posted: Nov. 17, 2029 8:03 PM EST

Note: Since TV DELETED my review on their website, I am reposting this on rateyourtrip.com where they can't touch it. It says something that they felt like they had to CENSOR me, don't you think?

Don't let Temporal Ventures lure you in with their false advertising! They're just trying to cheat you out of your money, or if you're really lucky maybe they'll thump you on the head and pry it from your fingers in the name of 'science' or 'intertemporal law'. But I'm getting ahead of myself.

I enrolled in Temporal Venture's 'Classic Caribbean' package. Take a moment to see what the trip to the year 1720 is SUPPOSED to include: http://temporalventures.com/ packages? $p=39284$. Treasure! Pirates! Adventure! Sound exciting? Let me tell you how the 'adventure' actually goes.

First off, the time jump makes you feel like SHIT, like after a night of drinking with my ex-wife. And when you finally crawl out of bed do they let you enjoy the sun? No, they have a two-hour orientation video. Maybe you'll make it past the first mention of temporal nodes or causality thresholds, but I didn't. Yawn. I didn't pay for a science lesson.

Then you meet wet-blanket Randy. He's the tour guide fun police for the trip. You know the type: little guy, glasses, with a stuck up, I'm-smarter-than-you attitude, always monotoning about what you should or shouldn't be doing. I had to spend most of my morning tuning him out. When I asked about treasure hunting, stick-up-his-butt Randy made some excuse about liability and pointed me to the 'pirate's wreck' tour - some old ship that got caught up on a reef and I guarantee you doesn't have an ounce of treasure on it by now. Meanwhile all the other guests are content to lay on the beach or sit at the bar and blab about how clear the sky is and that the air

$\rightarrow$ NATURE.COM

Follow Futures on

Facebook at:

go.nature.com/mtoodm smells so fresh. Whatever. Come home with a load of Spanish treasure and you can invest in a personal holodome and next-gen atmo-filter. You'll be able to lay on a beach whenever you want.

$\mathrm{Oh}$, and pirates? There was ONE pirate. Greasy Sid had figured out how to panhandle from the tourists - which goes to show that bums will be bums no matter what century

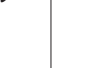
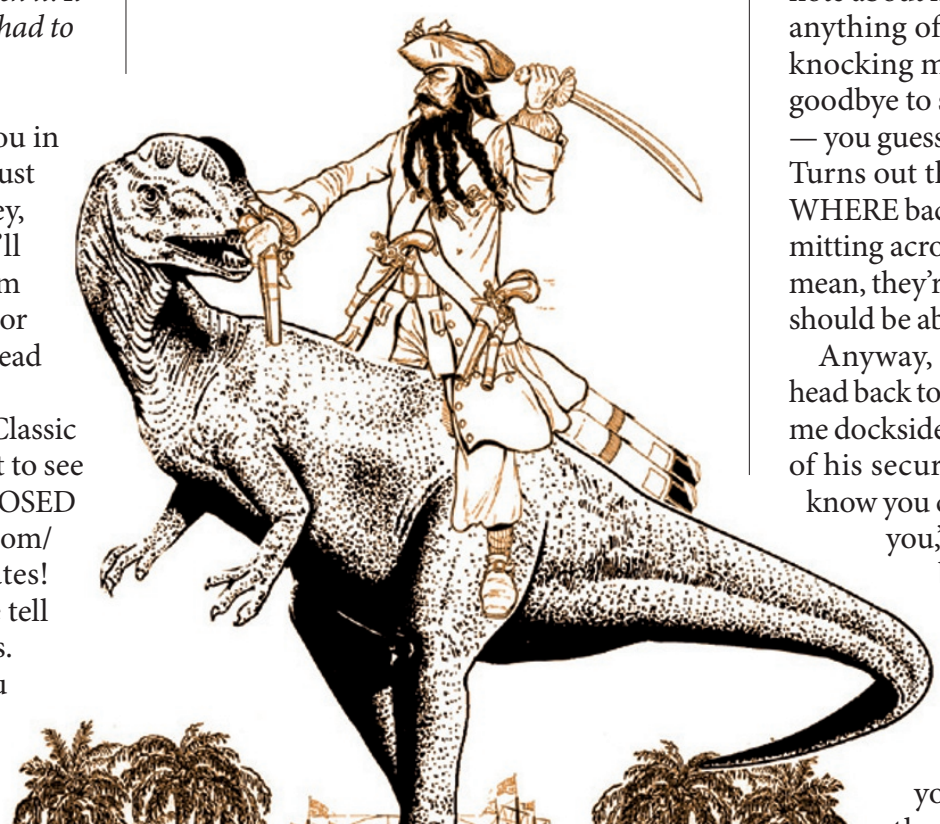
of gems, cups and plates of gold and silver, and enough jewellery to make my ex-wife's eyes pop.

I tried to send my ex a picture with a little note about how she thought I'd never make anything of myself and as she was always knocking my 'schemes', she could just say goodbye to seeing any part of the haul, but - you guessed it, my cell showed no signal. Turns out they don't have coverage ANYWHERE back then. Something about transmitting across the time link, I don't know. I mean, they're scientists, for god's sake! They should be able to figure something out.

Anyway, I bundle up what I can carry, head back to the resort, and guess who meets me dockside? Sonovabitch Randy, with two of his security goons flanking him. "You

know you can't take any of that home with you," he says, all smug, and then he blabs on about disrupting the time flow and I point out that he told us a dozen times that nothing we do here can mess up the future, and he says: "That's true, as long as you don't take anything FROM the past TO the future. Then all bets are off."

Which you'd THINK someone would have mentioned if it was such a big deal. But it's just a bunch of bullshit that he made up so he could 'confiscate' ${ }^{*}$ cough $^{*}$ STEAL ${ }^{\star} \operatorname{cough}^{\star}$ my treasure. So let's review. Temporal Ventures robbed me of my rightfully obtained property, manhandled me, searched my person - they even stole the doubloon I'd stuffed into my unmentionables because I KNEW they'd pull

it is - and I guess some intertemporal treaty says they're not legally able to run him off. I think he had tuberculosis or something, but I talked to him anyway. Well, with the right incentive (hint: pirates like Bacardi Gold way better than whatever booze they're used to) $\mathrm{HE}$, at least, was willing to talk about treasure. Even drew me a map on the back of a cocktail napkin.

So I, er, 'borrowed' some scuba gear and a skimmer. And damned if Greasy Sid didn't know what he was talking about. I had to swim through an underwater cave and almost got skewered by poisoned darts and I probably set off some ancient voodoo some crap like that - and then they had security glued to me for the rest of the trip so I couldn't even take a piss without one of them watching over my shoulder.

Well, if THAT'S what you want from your 'vacation' then go right ahead with Temporal Ventures. They've lost my business. I was looking forward to checking out their 'Jurassic Jaunt' package, but screw that. I bet they don't even let you ride the dinosaurs.

Scott C. Mikula is a husband, father, software developer, board gamer, and has been told he makes a mean chocolate-chip cookie. On his better days he is also a writer. 